\title{
Metabolizable Energy Levels for Free-Range Broiler Chickens
}

\author{
Luanna Lopes Paiva Copat \\ Faculty of Veterinary Medicine and Animal Science, Federal University of Mato Grosso do \\ Sul, Campo Grande, Mato Grosso do Sul, Brazil \\ E-mail: lu.paiva.lopes@gmail.com
}

Karina Marcia Ribeiro de Souza Nascimento (Corresponding author)

Faculty of Veterinary Medicine and Animal Science, Federal University of Mato Grosso do Sul. Av. Senador Filinto Muller, 2443, CEP:79074-460, Campo Grande, MS, Brazil

E-mail: karina.souza@ufms.br

\section{Charles Kiefer}

Faculty of Veterinary Medicine and Animal Science, Federal University of Mato Grosso do Sul, Campo Grande, Mato Grosso do Sul, Brazil

E-mail: charles.kiefer

\section{Patrícia Rodrigues Berno}

Faculty of Veterinary Medicine and Animal Science University of Mato Grosso do Sul,

Campo Grande, Mato Grosso do Sul, Brazil

E-mail: patricinhaberno@outlook.com

\section{Henrique Barbosa de Freitas}

Faculty of Veterinary Medicine and Animal Science, Federal University of Mato Grosso do Sul, Campo Grande, Mato Grosso do Sul, Brazil

E-mail: henrique_barbosa_7@yahoo.com.br

Thiago Rodrigues da Silva

Faculty of Veterinary Medicine and Animal Science, Federal University of Mato Grosso do 
Sul, Campo Grande, Mato Grosso do Sul, Brazil

E-mail: thiagoth_rodrigues@ @otmail.com

\author{
Natália Ramos Batista Chaves \\ Federal Institute of Mato Grosso, Campus of Alta Floresta. Alta Floresta, Mato Grosso, \\ Brazil. \\ E-mail: natalia.chaves@alf.ifmt.edu.br
}

Melissa Amin

Estácio de Sá University, Campo Grande, Mato Grosso do Sul, Brazil

E-mail: mellamin@ @otmail.com

\begin{abstract}
Patrícia Gomes Santana
Faculty of Veterinary Medicine and Animal Science, Federal University of Mato Grosso do Sul, Campo Grande, Mato Grosso do Sul, Brazil

E-mail: patricia_santana12@hotmail.com
\end{abstract}

Nadine Godoy de Oliveira

Faculty of Veterinary Medicine and Animal Science, Federal University of Mato Grosso do Sul, Campo Grande, Mato Grosso do Sul, Brazil

E-mail: nadinegodoy@hotmail.com

Received: Apr. 2, 2020

doi:10.5296/jas.v8i3.16666
Accepted: June 8, $2020 \quad$ Published: June 15, 2020

URL: https://doi.org/10.5296/jas.v8i3.16666

\begin{abstract}
The aim of this study was to evaluate the effect of dietary metabolizable energy levels on the performance and carcass yield of free-range broiler chickens from 1 to 84 days of age. A total of 900 male day-old naked neck lineage chicks were distributed in a completely randomized design between six levels of metabolizable energy $(2,700 ; 2,800 ; 2,900 ; 3,000 ; 3,100$ and $3,200 \mathrm{kcal} . \mathrm{kg}^{-1}$ diet) with six replications of 25 birds each. The increase in levels of dietary metabolizable energy resulted in a linear reduction of the feed intake, crude protein and
\end{abstract}


digestible lysine intakes, as well as in the protein body deposition and protein efficiency and linear improvements in the feed conversion ratio of chickens in all experimental phases. The carcass yield, wing and abdominal fat weight and percentage of abdominal fat reduced linearly by increasing the level of dietary metabolizable energy. The diet including 2700 $\mathrm{kcal} . \mathrm{kg}^{-1}$ of metabolizable energy in the diet of free-range broiler chickens in phases 1 to 28 , 28 and 56 and 57 to 84 days of age does not interfere in the broilers performance and results in a better carcass yield in the final period of production.

Keywords: broiler, colonial chicken, energy requirement, growth performance, naked neck, semi-intensive system

\section{Introduction}

The production of free-range broiler chickens results in differences in flavor, softness, and coloring as well as a lower fat content. Therefore, it can be used to meet the demands of a growing market niche regarding food safety and welfare of animal production (Faria et al., 2009; Souza et al., 2012), unlike chickens originating from conventional production.

The Ministério da Agricultura, Pecuária e Abastecimento (MAPA), is responsible for the regulation of the free-range broiler chickens, through the circular letter $n^{\circ} .07$ of 1999 , that lays down the following conditions for this category: 1) feed should contain only vegetable products; 2 ) it is prohibited to use any type of growth promoter ; 3 ) the animals may be reared in a chicken house up to 25 days of age (intensive system), after which period the birds must be released in a pasturage area of $3 \mathrm{~m}^{2}$ per bird; 4) slaughter must be carried out after at least 85 days of age; 5) the lineages used should be suitable for this purpose, the use of commercial lineage of broilers being prohibited (Brasil, 1999).

Unlike commercial broiler chickens, there is still no established energy requirement for that animal category in its different phases of production, however, some studies suggest that free-range broiler chickens require lower amounts of metabolizable energy and a lower energy: protein ratio in the diet compared with commercial lineage (Mendonça et al., 2008; Moreira et al., 2012).

The increase in the dietary metabolizable energy levels improves weight gain and feed conversion by including a lipid source in the feed (Sakomura et al., 2004). However, high amounts of energy provide an increase in deposition of abdominal fat in broilers (Santos et al., 2014).

The largest percentage of farmed poultry production costs is due to feed which represents 70 to $80 \%$ of the cost, which energetic ingredients are the most expensive ones (Santos et al., 2012). Associated with it, the main challenge in meeting the nutritional requirements of free-range broiler chickens is establishing an optimal level of metabolizable energy with maximum performance and low fat in the carcass.

On this way, the aim of this study was to evaluate the effect of dietary metabolizable energy levels on the growth performance and carcass quality during starter phase of free-range broiler chickens from 1 to 84 days of age. 


\section{Material and Methods}

\subsection{Birds, Experimental Design, Husbandry and Diets}

All the procedures adopted in the present study were approved by Institutional Ethics Committee (case no 558/2013) for Animal Use.

A total of 900 male day-old naked neck lineage chicks were allocated according to completely randomized design, in six treatments with six replications of 25 birds each, during the trial period of 84 days. The trial period was divided into three phases of production: initial phase (1 to 28 days), growth phase (29 to 56) and final phase (57 to 84 days).

Experimental diets consisted of 2,700; 2,800; 2,900; 3,000; 3,100 and 3,200 kcal.kg-1 of metabolizable energy. The diets are formulated to be isoproteic, isoaminoacidic and corn and soybean meal based in order to meet the nutritional requirements of semi-weight pullets, except in metabolizable energy, according to the recommendations of Rostagno et al. (2011) (Table 1).

Table 1. Percent composition and calculated values of the experimental diets ${ }^{1}$

\begin{tabular}{|c|c|c|c|c|c|c|c|c|c|c|c|c|c|c|c|c|c|c|}
\hline \multirow{3}{*}{$\begin{array}{l}\text { Ingredients } \\
\quad\left(\mathrm{g} \mathrm{kg}^{-1}\right)\end{array}$} & \multicolumn{5}{|c|}{1 to 28 days } & \multicolumn{8}{|c|}{29 to 56 days } & \multicolumn{5}{|c|}{57 to 84 days } \\
\hline & \multicolumn{18}{|c|}{ Metabolizable energy $\left(\mathrm{kcal} \mathrm{kg}^{-1}\right)$} \\
\hline & 2,700 & 2,800 & 2,900 & 3,000 & 3,100 & 3,200 & 2,700 & 2,800 & 2,900 & 3,000 & 3,100 & 3,200 & 2,700 & 2,800 & 2,900 & 3,000 & 3,100 & 3,200 \\
\hline Corn & 592.8 & 592.8 & 592.8 & 592.8 & 592.8 & 592.8 & 651.4 & 651.4 & 651.4 & 651.4 & 651.4 & 651.4 & 666.8 & 666.8 & 666.8 & 666.8 & 666.8 & 666.8 \\
\hline Soybean meal. $45 \%$ & 293.5 & 293.5 & 293.5 & 293.5 & 293.5 & 293.5 & 239.9 & 239.9 & 239.9 & 239.9 & 239.9 & 239.9 & 215.5 & 215.5 & 215.5 & 215.5 & 215.5 & 215.5 \\
\hline Soy oil & - & 11.4 & 22.8 & 34.1 & 45.5 & 56.9 & - & 2.9 & 14.3 & 25.7 & 37.1 & 48.4 & - & 3.4 & 14.8 & 26.2 & 37.6 & 48.9 \\
\hline Kaolin & 78.5 & 67.1 & 55.8 & 44.4 & 32.9 & 21.6 & 78.4 & 75.5 & 64.1 & 52.7 & 41.3 & 29.9 & 89.5 & 86.6 & 75.2 & 63.8 & 52.4 & 41.1 \\
\hline Dicalcium phosphate & 17.8 & 17.8 & 17.8 & 17.8 & 17.8 & 17.8 & 15.6 & 15.6 & 15.6 & 15.6 & 15.6 & 15.6 & 11.8 & 11.8 & 11.8 & 11.8 & 11.8 & 11.8 \\
\hline Mineral supplement ${ }^{2}$. & 1.0 & 1.0 & 1.0 & 1.0 & 1.0 & 1.0 & 1.0 & 1.0 & 1.0 & 1.0 & 1.0 & 1.0 & 1.0 & 1.0 & 1.0 & 1.0 & 1.0 & 1.0 \\
\hline Vitamin supplement ${ }^{3}$. & 1.0 & 1.0 & 1.0 & 1.0 & 1.0 & 1.0 & 1.0 & 1.0 & 1.0 & 1.0 & 1.0 & 1.0 & 1.0 & 1.0 & 1.0 & 1.0 & 1.0 & 1.0 \\
\hline Salt & 3.7 & 3.7 & 3.7 & 3.7 & 3.7 & 3.7 & 3.2 & 3.2 & 3.2 & 3.2 & 3.2 & 3.2 & 3.0 & 3.0 & 3.0 & 3.0 & 3.0 & 3.0 \\
\hline \multirow[t]{2}{*}{ DL-Methionine } & 0.96 & 0.96 & 0.96 & 0.96 & 0.96 & 0.96 & 0.25 & 0.25 & 0.25 & 0.25 & 0.25 & 0.25 & - & - & - & - & - & - \\
\hline & & & \multicolumn{16}{|c|}{ Nutrition values calculated ${ }^{*}$} \\
\hline $\mathrm{ME}\left(\mathrm{kcal}_{\mathrm{kg}} \mathrm{kg}^{-1}\right)$ & 2,700 & 2,800 & 2,900 & 3,000 & 3,100 & 3,200 & 2,700 & 2,800 & 2,900 & 3,000 & 3,100 & 3,200 & 2,700 & 2,800 & 2,900 & 3,000 & 3,100 & 3,200 \\
\hline $\mathrm{CP}\left(\mathrm{g} \mathrm{kg}^{-1}\right)$ & 180.0 & 180.0 & 180.0 & 180.0 & 180.0 & 180.0 & 160.0 & 160.0 & 160.0 & 160.0 & 160.0 & 160.0 & 150.0 & 150.0 & 150.0 & 150.0 & 150.0 & 150.0 \\
\hline Lysine dig $\left(\mathrm{g} \mathrm{kg}^{-1}\right)$ & 8.62 & 8.62 & 8.62 & 8.62 & 8.62 & 8.62 & 7.39 & 7.39 & 7.39 & 7.39 & 7.39 & 7.39 & 6.80 & 6.80 & 6.80 & 6.80 & 6.80 & 6.80 \\
\hline Met+Cys dig $\left(\mathrm{g} \mathrm{kg}^{-1}\right)$ & 6.19 & 6.19 & 6.19 & 6.19 & 6.19 & 6.19 & 5.07 & 5.07 & 5.07 & 5.07 & 5.07 & 5.07 & 4.60 & 4.60 & 4.60 & 4.60 & 4.60 & 4.60 \\
\hline Calcium $\left(\mathrm{g} \mathrm{kg}^{-1}\right)$ & 9.40 & 9.40 & 9.40 & 9.40 & 9.40 & 9.40 & 8.15 & 8.15 & 8.15 & 8.15 & 8.15 & 8.15 & 7.80 & 7.80 & 7.80 & 7.80 & 7.80 & 7.80 \\
\hline $\mathrm{Pa}\left(\mathrm{g} \mathrm{kg}^{-1}\right)$ & 4.30 & 4.30 & 4.30 & 4.30 & 4.30 & 4.30 & 3.80 & 3.80 & 3.80 & 3.80 & 3.80 & 3.80 & 3.05 & 3.05 & 3.05 & 3.05 & 3.05 & 3.05 \\
\hline
\end{tabular}

${ }^{1}$ Diets formulated according to nutritional requirements recommended by Rostagno et al. (2011) for semi-weighted poultry in the different stages of breeding. ${ }^{2}$ Mineral supplement $g$ $\mathrm{kg}^{-1}: 11.00 \mathrm{mg}$ zinc; $3.04 \mathrm{mg}$ panthotenic acid; $0.22 \mathrm{mg}$ iodine; $0.06 \mathrm{mg}$ selenium; $90 \mathrm{mg}$ choline chloride; $8.48 \mathrm{mg}$ Iron; $2.64 \mathrm{mg}$ copper; $15.15 \mathrm{mg}$ manganese. ${ }^{3}$ Vitamin supplement $\mathrm{g} \mathrm{kg}^{-1}: 2.400 \mathrm{IU}$ Vitamin A; 480 IU Vitamin D3; $0.32 \mathrm{mg}$ Vitamin K3; $0.51 \mathrm{mg}$ Vitamin B1; $1.38 \mathrm{mg}$ Vitamin B2; $0.64 \mathrm{mg}$ Vitamin B6; $2.88 \mathrm{mg}$ Vitamin B12; $3.00 \mathrm{mg}$ Vitamin E; 7.12 mg Niacin. *ME: metabolizable energy; CP: Crude protein; Dig: digestible; Met + Cys dig: methionine + cystine digestible; Pa: Available phosphorus.

The different levels of metabolizable energy were obtained from the inclusion of soy oil in replacement of kaolin. Feed and water were provided ad libitum throughout all the experimental period. 


\subsection{Animal Management}

The chickens were housed in a shed covered with fiber cement roof and divided into $2.5 \mathrm{~m}^{2}$ pits with a dirt floor, and the litter material was pine shavings and the pens were equipped with an electric incandescent bulb, tubular feeder and bell drinking type. Each box had access to the pasturage area formed by grass. However, the birds remained confined until 28 days of age, then they had free access to the pasturage area until the end of the experimental period.

The light program was $24 \mathrm{~h}$ (natural + artificial) in the first 14 days and natural light until the end of the trial period. The temperature and relative humidity of the air were monitored daily at 7 am and 5pm, using a digital thermo-hygrometer.

\subsection{Assessments}

On the first day of age, the initial weight of the birds was measure for the weight standardization of the experimental units. Poultry and diet were weighed weekly. Performance was evaluated in the accumulated periods from 1 to 28,1 to 56 and 1 to 84 days by studying the variables: body weight $\left(\mathrm{g} \mathrm{kg}^{1}\right)$, weight gain $\left(\mathrm{g} \mathrm{kg}^{-1}\right)$, feed intake $\left(\mathrm{g} \mathrm{kg}^{-1}\right)$, metabolizable energy intake $\left(\mathrm{kcal}_{\mathrm{kg}} \mathrm{kg}^{-1}\right)$, crude protein intake $\left(\mathrm{g} \mathrm{kg}^{-1}\right)$, digestible lysine intake $\left(\mathrm{g} \mathrm{kg}^{-1}\right)$, protein utilization efficiency $(\mathrm{g}: \mathrm{g})$, feed conversion $(\mathrm{g}: \mathrm{g})$, live ability (\%). Weight gain and feed conversion were corrected by mortality according to Sakomura and Rostagno (2007).

The protein utilization efficiency of the diet was determined by dividing the weight gain by the percentage of protein ingested during the accumulated experimental periods, either 1 to 28,1 to 56 or 1 to 84 days.

The protein and lipid content of the carcass were analyzed at the end of each feeding phase. This was determined by selecting 12 chicks with control of age, one bird per box from 28 and 56 days and two birds per box at 84 days of age, with body weights close to the mean $( \pm 10 \%)$ weight of the experimental unit. These birds were subjected to fasting of solids for 6 hours (except those slaughtered at a day of age) and subsequently euthanized by cervical dislocation, followed by bleeding, scalding, plucking and eviscerated. The carcasses except for the feet and head were ground and packed in plastic bags, identified, and stored in the freezer for later centesimal analysis.

The ground carcass samples were removed from the freezer and weighed on Petri plates and placed in a drying kiln at $105^{\circ} \mathrm{C}$ for $72 \mathrm{~h}$. These were subsequently processed in a ball mill for the analysis of dry matter, crude protein and ethereal extract according to the methodology described by Silva and Queiroz (2006). All data of depositions were calculated according to per the difference in ages from the first day and expressed in relation to the dry matter of the carcass.

On the 84th day, before carcasses were ground, they were weighed using a semi analytical balance $( \pm 0.01 \mathrm{~kg})$ to evaluate the carcass weight and yield, chest, legs (thighs + upper thighs), wings, back weight and the percentage of abdominal fat (following removal of the region near to cloaca). 
Carcass yield $(\%)$ was calculated by the relationship between the weight of the hot carcass (eviscerated, no feet and head) and the weight of the bird after fasting before slaughter: Carcass yield $(\%)=$ Weight of hot carcass $(\mathrm{kg}) \times 100 \div$ bird weight before slaughter.

The yield of cuts was calculated by the relationship between the weight of the cut and the weight of the hot carcass (eviscerated, no feet or head): Cut yields $(\%)=$ cut weight $\mathrm{x} 100 \div$ hot carcass weight.

\subsection{Statistical Analysis}

The data were submitted to an analysis of variance, and subsequently to the analysis of linear and quadratic regression using the SAS program, version 9.1, to 5\% significance.

Variables were analyzed according to the following mathematical model: $\mathrm{Yij}=\mu+\mathrm{Ti}+\mathrm{eij}$, in which Yij = observation of experimental unit subjected to treatments $\mathrm{Ti} ; \mu=$ general constant and eij $=$ random error associated to each observation.

\section{Results}

\subsection{Environment}

The average temperature values minimum $\left(23.5^{\circ} \mathrm{C}\right)$, maximum $\left(31.0^{\circ} \mathrm{C}\right)$ and relative humidity of air $(71.36 \%)$ remained high during the experimental period.

\subsection{Performance and Carcass}

There was a linear reduction $(\mathrm{P}<0.05)$ in the feed intake, feed conversion ratio and in digestible crude protein and lysine intakes of the chickens fed in dietary metabolizable energy during all periods of production evaluated (Table 2).

The increase in the dietary metabolizable energy levels did not change $(\mathrm{P}>0.05)$ the energy intake.

Protein utilization efficiency improved $(\mathrm{P}<0.05)$ as metabolizable energy levels in the diet increased, while the body protein deposition reduced linearly $(\mathrm{P}<0.05)$. For all periods there was no observed effect $(\mathrm{P}>0.05)$ caused by the dietary metabolizable energy levels on the body fat deposition of the birds.

As the dietary metabolizable energy levels increased, the carcass weight was linearly reduced $(\mathrm{P}<0.05)$ (Table 3). Among the cuts, only the weight of wings was influenced by the metabolizable energy levels and reduced linearly as the energy level increased in the diets. An influence on abdominal fat was seen, with a significant $(\mathrm{P}<0.05)$ increase in deposition of abdominal fat seen as dietary metabolizable energy increased.

\section{Discussion}

The correlation between the linear reduction in feed intake and increase in the level of dietary metabolizable energy observed in this study is based mainly on the glycostatic theory that acts at the satiety center, controlled by the hypothalamus located in the cerebral cortex (Richards and Proszkoiec-Weglarz, 2007). However, when the inclusion of energy in the diet is high, 
there is a reduction in broiler feed intake (Dairo et al., 2010, Barbosa et al., 2012, Rahman et al., 2014). In general, the higher the energy level of the diet, the lower the voluntary consumption of the animals.

These results are to those similar by those obtained by Mendonça et al. (2007), using 2,600 to $3,200 \mathrm{kcal} . \mathrm{kg}^{-1}$ of ME in the initial phase, 2,700 to 3,300 kcal. $\mathrm{kg}^{-1}$ of ME in the growth phase and 2,800 to 3,400 kcal. $\mathrm{kg}^{-1}$ of ME in the final phase, where they observed a linear reduction with the increase in the energy density of the diet. Similarly, Zanusso et al. (1999) and Lana et al. (2004), which increased the energy levels from 2,850 to 3,350 kcal. $\mathrm{kg}^{-1}$ of ME of the broilers diet, found a decrease in feed intake by birds. Other authors, using fast-growing lineage and increasing levels of metabolizable energy, observed a linear reduction in feed intake, as a function of the increase in diet energy density (Oliveira Neto et al., 1999; Ferreira et al., 2015).

Table 2. Performance of free-range broiler chickens subjected to diets with different levels of metabolizable energy

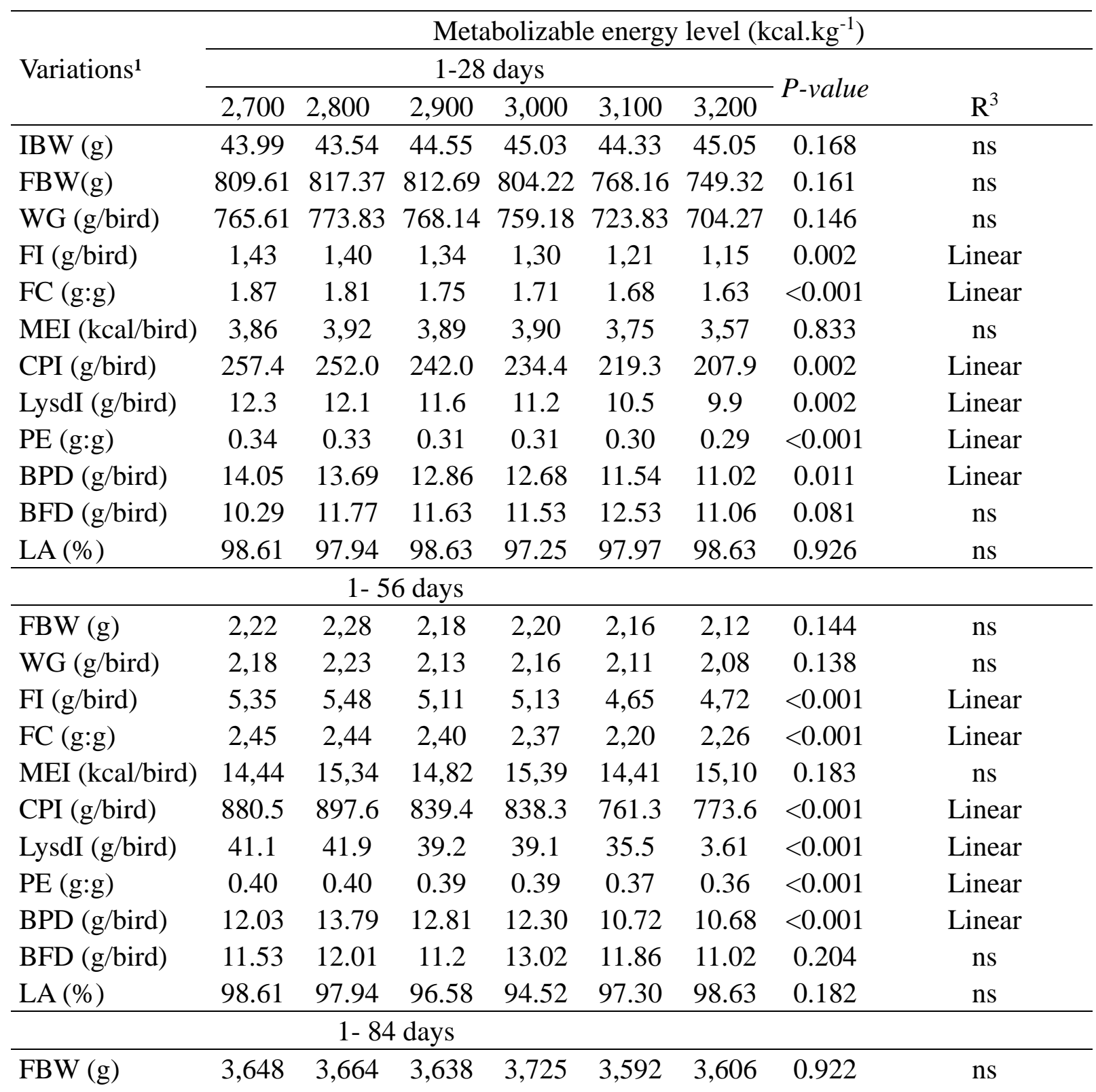




\begin{tabular}{lcccccccc}
\hline WG (g/bird) & 3,604 & 3,621 & 3,593 & 3,680 & 3,548 & 3,561 & 0.923 & ns \\
FI (g/bird) & 11,13 & 11,46 & 11,26 & 10,51 & 9,82 & 9,68 & 0.001 & Linear \\
FC (g:g) & 3,08 & 3,16 & 3,13 & 3,86 & 2,77 & 2,72 & 0.001 & Linear \\
MEI (kcal/bird) & 30,05 & 32,09 & 32,65 & 31,53 & 30,44 & 30,98 & 0.454 & ns \\
CPI (g/bird) & 1.73 & 1.77 & 1.71 & 1.61 & 1.51 & 1.50 & 0.0002 & Linear \\
LysdI (g/bird) & 79.5 & 81.7 & 78.8 & 74.1 & 69.5 & 68.8 & 0.0002 & Linear \\
PE (g:g) & 0.48 & 0.49 & 0.48 & 0.44 & 0.43 & 0.42 & 0.0005 & Linear \\
BPD (g/bird) & 18.84 & 19.07 & 18.23 & 18.55 & 14.84 & 16.79 & 0.016 & Linear \\
BFD (g/bird) & 18.76 & 17.84 & 18.92 & 18.22 & 17.89 & 19.05 & 0.801 & $\mathrm{~ns}$ \\
LA (\%) & 96.58 & 96.58 & 95.88 & 91.16 & 97.30 & 97.27 & 0.150 & $\mathrm{~ns}$ \\
\hline
\end{tabular}

${ }^{1}$ IBW: Initial body weight; FBW: Final body weight; WG: Weight gain; FI: Feed intake; FC: Feed conversion; MEI: Metabolizable energy intake; CPI: Crude protein intake; LysdI: Digestible lysine intake; PE: Protein utilization efficiency; BPD: Body protein deposition; BFD: Body fat deposition; LA: Liveability. ${ }^{2} \mathrm{CV}$ : Coefficient of variation. ${ }^{3}$ Regression - FI $28 \mathrm{~d}=2994-0.5706 \mathrm{x} . \mathrm{R}^{2}=0.98 ;$ FC $28 \mathrm{~d}=3.136-0.0005 . \mathrm{R}^{2}=0.98 ;$ CPI $28 \mathrm{~d}=53.888-0.0103 . \mathrm{R}^{2}$ $=0.98$; LysdI $28 \mathrm{~d}=2.583-0.0005 . \mathrm{R}^{2}=0.98$; BPD $28 \mathrm{~d}=25.952-0.005 \mathrm{x} . \mathrm{R}^{2}=0.53$; PE $28 \mathrm{~d}=$ $0.5615-8 \mathrm{E}-05 \mathrm{x} . \mathrm{R}^{2}=0.98$; FI 56d= 9814.4-1.6062x. $\mathrm{R}^{2}=0.82$; FC 56d=3.810-0.0005x. $\mathrm{R}^{2}=$ 0.79; CPI 56d=162.76-0.027x. $\mathrm{R}^{2}=0.84$; LydI 56d=7.6121-0.0013x. $\mathrm{R}^{2}=0.84$; BPD 56d= 30.992-0.006x. $R^{2}=0.97$; PE 56d=0.6534-9E-05x. $R^{2}=0.95$; FI 84d=2153.3-36902x. $R^{2}=$ 0.82 ; FC $84 d=5.709-0.0009 x . R^{2}=0.81$; CPI $84 d=336.29-0.0585 x . R^{2}=0.86$; LysdI $84 d=$ 15.489-0.0027x. $\mathrm{R}^{2}=0.84$; BPD 84d=36.790-0.0065x. $\mathrm{R}^{2}=0.55$; PE 84d=0.8933-0.0001x. $\mathrm{R}^{2}=0.85$.

Table 3. Absolute values and yields of carcass and cuts of free-range broiler chickens subjected of diets with different metabolizable energy levels at 84 days of age

\begin{tabular}{|c|c|c|c|c|c|c|c|c|}
\hline \multirow{2}{*}{ Variations } & \multicolumn{6}{|c|}{ Metabolizable energy levels ( $\left.\mathrm{kcal} \mathrm{kg}^{-1}\right)$} & \multirow{2}{*}{ P-value } & \multirow{2}{*}{$\mathrm{R}^{1}$} \\
\hline & 2,700 & 2,800 & 2,900 & 3,000 & 3,100 & 3,200 & & \\
\hline Carcass $(\mathrm{g})$ & 2,607 & 2,673 & 2,597 & 2,625 & 2,475 & 2,513 & 0.046 & Linear \\
\hline Breast $(\mathrm{g})$ & 703.50 & 716.50 & 712.50 & 698.33 & 664.92 & 668.83 & 0.156 & ns \\
\hline TUT $(g)$ & 791.08 & 821.67 & 793.50 & 798.92 & 752.25 & 755.50 & 0.161 & ns \\
\hline Wings $(g)$ & 286.33 & 294.33 & 278.00 & 286.50 & 273.00 & 269.58 & 0.040 & Linear \\
\hline Back $(g)$ & 672.75 & 683.58 & 662.50 & 684.17 & 623.08 & 663.17 & 0.296 & ns \\
\hline $\mathrm{FAB}(\mathrm{g})$ & 107.04 & 141.58 & 154.04 & 126.25 & 152.54 & 148.79 & 0.036 & Linear \\
\hline Carcass $(\mathrm{kg} / 100 \mathrm{~kg})$ & 72.32 & 72.66 & 72.31 & 72.53 & 71.07 & 71.09 & 0.065 & ns \\
\hline Breast $(\mathrm{kg} / 100 \mathrm{~kg})$ & 27.03 & 26.80 & 27.52 & 26.54 & 26.85 & 26.63 & 0.829 & ns \\
\hline TUT (kg/100 kg) & 30.31 & 30.73 & 30.49 & 30.43 & 30.59 & 30.04 & 0.920 & ns \\
\hline Wings $(\mathrm{kg} / 100 \mathrm{~kg})$ & 10.99 & 11.02 & 10.70 & 10.91 & 11.04 & 10.72 & 0.550 & ns \\
\hline Back (kg/100 kg) & 26.18 & 25.53 & 25.49 & 26.10 & 25.17 & 26.39 & 0.669 & ns \\
\hline FAB $(\mathrm{kg} / 100 \mathrm{~kg})$ & 2.95 & 3.87 & 4.30 & 3.47 & 4.33 & 4.19 & 0.017 & Linear \\
\hline
\end{tabular}

TUT (Thigh+upperthigh). FAB (Fat abdominal). ${ }^{1}$ Regression - Carcass (g) $=3457.7-0.2967 \mathrm{x}$, $\mathrm{R}^{2}=0.56$; Wings $(\mathrm{g})=398.66-0.039 \mathrm{x}, \mathrm{R}^{2}=0.63 ; \mathrm{FAB}=41.856+0.0611 \mathrm{x}, \mathrm{R}^{2}=0.38$.

The voluntary regulation of feed intake according to the level of dietary metabolizable energy 
justifies the absence of a difference in the metabolizable energy consumption among the treatments observed in this study. It is usually found that birds compensate for the low energy density of the diet by increasing feed intake until energy demand is reached (Schneiders et al., 2016). This result can be considered as positive, suggesting that free-range broiler chickens may be submitted to diets with lower metabolizable energy levels without compromising performance (Sakomura et al., 2004).

The correlation between lower intakes of lysine and crude protein and increases in the energy level of the diet found in this study, is in accordance with the response to the lower feed intake observed in birds fed diets with higher energy levels. Thus, even variations in energy : nutrient ratio of the experimental diets, body weight and weight gain of broiler chickens were not affected. This is possibly because of the better digestibility and metabolization of the nutrient lysine, since the energy content met the energy requirement of the chickens, while the consumption of metabolizable energy by the birds was not influenced by the different energy levels of the diet.

The improvement in the feed conversion observed as the metabolizable energy levels of the diets increased may be associated with the lower caloric increment. Which includes all of the energy generated by the processes of digestion, absorption and nutrient metabolism when the inclusion of lipid source occurs in relation to soybean oil in the broiler diet (Sakomura and Rostagno, 2007). This results in an improvement in feed conversion and bird performance due to better dietary energy metabolism.

Similarly, Ferreira et al. (2015) observed an improvement in the feed conversion of broilers of the $\mathrm{Cobb}^{\circledR}$ strain as metabolizable energy levels increased between 2,800; 2,900; 3,000; 3,100; 3,200 and 3,300 $\mathrm{kcal} \mathrm{kg}^{-1}$ rations.

The reduction in carcass weight as the feed energy level increased may be associated with a lower intake of feed and nutrients in the free-range broiler chicken. The lower intake of feed, which shows a loss in the utilization of these nutrients and in the rates of protein deposition, leads to suboptimal carcass composition (Muniz et al., 2016).

For the cuts, only the percentage of wings presented differences in this study, an observation which agreed with the study of Mendes et al. (2004). However, these authors stated that there was no consistency in the results. Since the literature does not report the effect of dietary energy levels on the percentage of wings, this result should be better investigated.

The increase in dietary energy levels influenced the deposition of abdominal fat in chickens. As dietary energy levels were increased, abdominal fat also increased linearly, demonstrating that excess energy is deposited as fat by chickens. According to Nascimento et al. (2004), the feed intake with higher energy levels without an adequate balance of protein in the diet limits the growth of lean tissue and, for this reason, the energy excess is deposited only in the form of fat, instead of increasing the muscle mass. In the same way, Laganá et al. (2005) observed the occurrence of greater deposition of abdominal fat increasing the amount of energy available for synthesis, so excess feed energy is positively correlated to lipid deposition in most animals. 


\section{Conclusion}

The increase in the dietary metabolizable energy level for free-range broiler chickens without the adjustment of nutrients in relation to the energy level does not enhance the weight or weight gain of birds, reduces feed intake, improves feed conversion, but increases the deposition of abdominal fat from 1 to 84 days of age. It is recommended to use the level of 2,700 kcal.kg-1 of metabolizable energy in diets of free-range broiler chicken in the period from 1 to 84 days of age. Excess energy intake may result in increased fat deposition which affects meat quality and consumer health.

\section{Acknowledgment}

The authors thank CNPq for the financial support for project development and FUNDECT - MS for scholarship availability. This study was financed in part by the Coordenação de Aperfeiçoamento de Pessoal de Nível Superior - Brasil (CAPES) - Finance Code 001. The present study was carried out with support from the Federal University of Mato Grosso do Sul UFMS/MEC - Brazil.

\section{References}

Barbosa, N. A. A., Sakomura, N. K., \& Bonato, M. A. (2012). Enzimas exógenas em dietas de frangos de corte: desempenho. Ciência Rural, (42), 1497-1502. http://dx.doi.org/10.1590/S0103-84782012000800027

BRASIL.Circular Letter DOI / DIPOA No. 007/99, of May 19, 1999. Standardization and Commercialization of Free-range Broiler Chicken." Official Daily of the Federative Republic of Brazil, MAPA, Brasília, DF, May 19.

Dairo, F. A. S., Adesehinwa, A. O. K., \&Oluwasola, T. A. (2010). High and low dietary energy and protein levels for broiler chickens. African Journal of Agricultural Research, (5), 2030-2038. https://doi.org/10.5897/AJAR10.254

Faria, B. P., Bressan, M. C., Souza, X. R., Rodrigues, E. C., Cardoso, G. P., \& Gama, L. T. (2009). Composição proximal e qualidade da carne de frangos das linhagens Paraíso Pedrês e Pescoço Pelado. Revista Brasileira de Zootecnia, (38), 2455-2464. https://doi.org/10.1590/s1516-35982009001200023

Ferreira, G. S., Pinto, F. M., Garcia Neto, M., Ponsano, E. H. G., Gonçalves, C. A., Bossolani, I. L. C., \& Pereira, A. G. (2015). Ajuste preciso do nível de energia na dieta de frangos de corte para controle do desempenho e da composição lipídica da carne. Ciência Rural, (45), 104-110. https://doi.org/10.1590/0103-8478cr20130206

Laganá, C., Ribeiro, L. M. A., Gonzalez, D. H. F., Lacerda, A. L., Terra, R. S., \& Barbosa, R. P. (2005). Suplementação de vitaminas e minerais orgânicos nos parâmetros bioquímicos e hematológicos de frangos de corte em estresse por calor. Boletim da Indústria Animal, (62), 157-165.

Lana, S. R. V., Bastos, E. C. G., Lana, G. R. Q., Silva Junior, R. G. C., Lana, A. M. Q., Rabelo, C. B. V., \& Barboza, W. A. (2004). Exigência de energia metabolizável para frangos 
de corte criados em região de clima tropical. In: REUNIÃO ANUAL DA SOCIEDADE BRASILEIRA DE ZOOTECNIA, 41., 2004, Campo Grande. Anais... Campo Grande: SBZ. 1 CD-Rom.

Mendes, A. A., Moreira, J., Oliveira, E. D., Garcia, E. A., Almeida, M. D., \& Garcia, R. G. (2004). Efeito da energia alimentar sobre o desempenho, rendimento de carcaça e gordura abdominal de frangos de corte. Revista Brasileira de Zootecnia, (33), 2300-2307.

Mendonça, M. D. O., Sakomura, N. K., Santos, F. R. D, Freitas, E. R., Fernandes, J. B. K., \& Barbosa, N. A. A. (2008). Níveis de energia metabolizável para frangos de corte de crescimento lento semi-confinados. Revista Brasileira de Zootecnia, (37), 1433-1440. https://doi.org/10.1590/s1516-35982008000800014

Mendonça, O. M., Sakomura, K. N., Santos, R.F., Barbosa, A. A. N., Fernandes, K. B. J., \& Freitas, R. E. (2007). Níveis de energia metabolizável e relações energia:proteína para aves de corte de crescimento lento criadas em sistema semiconfinado. Acta Scientiarum Animal Science, (29), 23-30. https://doi.org/10.4025/actascianimsci.v29i1.248

Moreira, A. S., Santos, M. S. V., Vieira, S. S., Tavares, F. B., \& Manno, M. C. (2012). Desempenho de frangos caipiras alimentados com rações contendo diferentes níveis de energia metabolizável. Arquivo Brasileiro de Medicina Veterinária e Zootecnia, 64, 1009-1016. https://doi.org/10.1590/S0102-09352012000400030

Muniz, J. C. L., Barreto, S. L. T., Mencalha, R., Viana, G. S., Reis, R. S., Ribeiro, C. L. N., Hannas, M. I., \&Albino, F. L. T. (2016). Níveis de energia metabolizável para codornas de corte de 15 a 35 dias de idade. Ciência Rural, 46, 1852-1857. https://doi.org/10.1590/0103-8478cr20141666

Nascimento, C. C. C., Gomes, P. C., \&Albino, L. F. T. (2004). Determinação dos valores energéticos de alguns óleos e gorduras para pintos de corte machos e fêmeas aos 21 dias de idade. Revista Brasileira de Zootecnia, 33, 375-385. https://doi.org/10.1590/s1516-35982004000200014

Oliveira Neto, A. R., Oliveira, R. F. M., Donzele, J. L., Albino, T. F. L, Valerio, R. S., \& Carmo, M. H. (1999). Níveis de energia metabolizável para frangos de corte no período de 22 a 42 dias de idade mantidos em condições de estresse de calor. Revista Brasileira de Zootecnia, 28, 1054-1062. https://doi.org/10.1590/s1516-35981999000500022

Rahman, A., Saima., Pasha, T. N., Younus, M., Abbas, Y., \& Ditta, Y. A. (2014). Effect of multi-enzymes supplementation on growth performance of broiler. Pakistan Journal of Zoology, 46, 417-422.

Richards, M. P., \& Proszkowiec-Welglarz, M. (2007). Mechanisms of regulating feed intake, energy expenditure, and body weight in poultry. Poultry Science, 86, 1478-1490. https://doi.org/10.1093/ps/86.7.1478 
Rostagno, H. S., Albino, L. F. T., Donzele, J. L., Gomes, P. C., Oliveira, R. F., Lopes, D. C., Ferreira, A. S., \& Barreto, S. L. T. (2011). Tabelas brasileiras para aves e suínos: composição de alimentos e exigências nutricionais. (3. ed.) Viçosa: UFV, 252.

Sakomura, N, K., Longo, F. A., Rabello, C. B., Watanabe, K., Pelícia, K., \&Freitas, E. R. (2004). Efeito do nível de energia metabolizável da dieta no desempenho energético e no metabolismo de frangos de corte. Revista Brasileira de Zootecnia, 33, 1758-1767. https://doi.org/10.1590/s1516-35982004000700014

Sakomura, N. K., \& Rostagno, H. S. (2007). Métodos de pesquisa em nutrição de monogástricos. Jaboticabal: FUNEP UNESP, 2007, 283.

Santos, F. R., Stringhini, J. H., Minafra, C. S., Almeida, R. R., Oliveira, P. R., Duarte, E. F., Silva, R. B., \&Café, M. B. (2014). Formulação de ração para frangos de corte de crescimento lento utilizando valores de energia metabolizável dos ingredientes determinada com linhagens de crescimento lento e rápido. Arquivo Brasileiro de Medicina Veterinária e Zootecnia, 66, 1839-1846. https://doi.org/10.1590/1678-6402

Santos, M. S. V., Vieira, S. S., Tavares, F. B, Andrade P. D. A., Manno, M. C, Costa, H. S, \& Moreira, A. D. S. (2012). Desempenho, carcaça e cortes de frangos caipira francês barré (gris barré cou plumé. Archivos de Zootecnia, 61, 287-295. https://doi.org/10.4321/s0004-05922012000200013

Schneiders, J. L., Nunes, R. V., Savoldi, T. L., Borsatti, L., Schöne, R. A, Frank, R., Bayerle, D. F., \& Silva, I. M. (2016). Performance of broiler chickens at pre starter and starter phases using diets with different metabolizable energy values of ingredients, at different ages. Ciência Rural, Santa Maria, 46, 1846-1851. https://doi.org/10.1590/0103-8478cr20150224

Silva, D. J. A., \& Queiroz, A. C. (2006). Análise de alimentos (métodos químicos e biológicos) (3.ed). Viçosa, MG: Editora UFV.

Souza, X. R., Faria, P. B., \& Bressan, M. C. (2012). Qualidade da carne de frangos de corte caipiras abatidos em diferentes idades. Arquivo Brasileiro de Medicina Veterinária e Zootecnia, 64,479-487. https://doi.org/10.1590/s0102-09352012000200031

Zanusso, J. T., Oliveira, M. F. R., Donzele, J. L., Ferreira, A. R., Rostagno, S. H., Euclydes, F. R., \& Valerio, R. S. (1999). Níveis de Energia Metabolizável para Frangos de Corte de 1 a 21 Dias de Idade Mantidos em Ambiente de Conforto Térmico. Revista Brasileira de Zootecnia, 28(5),1068-1074. https://doi.org/10.1590/s1516-35981999000500024

\section{Copyright Disclaimer}

Copyright for this article is retained by the author(s), with first publication rights granted to the journal.

This is an open-access article distributed under the terms and conditions of the Creative Commons Attribution license (http://creativecommons.org/licenses/by/4.0/). 